\title{
TANTANGAN PENDIDIKAN AGAMA KRISTEN DI ERA REVOLUSI INDUSTRI 4.0 DAN PASCA KEBENARAN
}

\author{
Mark Phillips Eliasaputra, Martina Novalina, Ruth Judica Siahaan \\ Sekolah Tinggi Teologi Ekumene Jakarta \\ martina@sttekumene.ac.id
}

\begin{abstract}
The Industrial Revolution Era 4.0 had an impact on everything, including in the lives of Christians. This paper aims to show how Christian Religious Education can play a role in guiding Christian young generation in responding to changes in the Industrial Revolution 4.0 era and the rapid hoax due to post-truth phenomena. With descriptive studies and literature study methods, conditions and challenges will be described, especially in connection with the use of devices as technological tools, as well as the role of PAK in conveying the truth and being a means to guide young people who are able to be witnesses of Christ who must uphold the truth and build good relationships with others.
\end{abstract}

Keywords: industrial revolution 4.0, post truth, gadget, building relationships, Christian Education

\begin{abstract}
Abstrak. Era Revolusi Industri 4.0 berdampak dalam segala hal, termasuk dalam kehidupan orang Kristen. Tulisan ini bertujuan untuk memperlihatkan bagaimana Pendidikan Agama Kristen dapat berperan dalam membimbing generasi muda Kristen dalam menyikapi perubahan di era Revolusi Industri 4.0 serta derasnya hoaks akibat fenomena pasca kebenaran. Dengan kajian deskriptif dan metode studi kepustakaan, akan digambarkan kondisi dan tantangan yang dihadapi, khususnya sehubungan dengan penggunaan gawai sebagai piranti teknologi, serta peran PAK dalam menyampaikan kebenaran dan menjadi sarana untuk membimbing generasi muda yang sanggup menjadi saksi-saksi Kristus yang harus memegang teguh kebenaran dan membangun relasi yang baik dengan sesama.
\end{abstract}

Kata Kunci: revolusi industri 4.0, pasca kebenaran, gawai, membangun relasi, Pendidikan Agama Kristen

\section{PENDAHULUAN}

Perkembangan teknologi yang pesat dewasa ini telah mengubah banyak hal dalam kehidupan manusia. Cara manusia hidup, bekerja, belajar, beribadah, hingga cara berelasi dengan sesama sekarang sudah sangat berbeda dengan beberapa tahun yang lalu. Sekalipun terobosan-terobosan baru di bidang teknologi seperti nanoteknologi, bioteknologi, pencetakan 3D, robotika masih di tahap awal dan juga lebih merasuk industri manufaktur, namun kemajuan teknologi Mark Phillips Eliasaputra, Martina Novalina, Ruth Judica Siahaan 
telekomunikasi dengan Internet dan gawai (gadget) beserta produk dan layanan baru yang tumbuh sebagai akibatnya, seperti komunikasi daring (online), pembayaran elektronik, ojek daring, perdagangan elektronik (e-commerce) mulai membentuk pergeseran paradigma mengenai bagaimana orang berkomunikasi, berelasi dengan sesama, mencari berita dan informasi, mencari hiburan, juga usaha mengenal Allah. Inilah yang disebut oleh para pakar sebagai Revolusi Industri 4.0.

Survei yang diadakan oleh Asosiasi Penyelenggara Jasa Internet Indonesia (APJII) menunjukkan bahwa jumlah pengguna Internet di Indonesia pada 2018 mencapai 171,17 juta jiwa, atau $64,8 \%$ dari total populasi penduduk Indonesia sebanyak 264,16 juta orang. Penetrasi pengguna Internet ini meningkat lebih dari 10\% dibandingkan dengan survei yang sama pada 2017. Adapun berdasarkan kelompok usianya, kelompok yang jumlah penggunanya lebih dari separuh adalah usia 10 hingga 44 tahun. (APJII 2019). Di satu sisi, ini tentu positif di bidang pengetahuan dan pendidikan, namun di sisi lain, muncullah tantangan terhadap eksistensi manusia sebagai makhluk sosial. Manusia tetap hidup bersama dengan manusia lain, namun cara berkomunikasinya sudah berubah. Mereka lebih banyak berkomunikasi dengan orang lain yang tidak terlihat secara langsung melalui gawai di tangan mereka dibandingkan dengan orang yang duduk di sebelahnya.

Salah satu bentuk inovasi dalam Revolusi Industri 4.0 adalah pemanfaatan media sosial yang mengalirkan informasi begitu derasnya tanpa henti kepada masyarakat, sekaligus juga mengubah posisi masyarakat dari pemirsa yang pasif menjadi produsen informasi yang aktif. Melalui Facebook, Twitter, Instagram, 
YouTube dan sebagainya, konten informasi yang mencapai masyarakat telah berubah dari karya jurnalistik dan ilmiah beserta norma dan etika yang melekat padanya menjadi karya bebas ciptaan siapa saja, di mana karya seni dan tulisan cerdas bercampur dengan sampah dan kebohongan.

Alhasil, orang menjadi kesulitan memilah yang mana yang asli dan mana yang bohong. Konten hoaks dan berita palsu yang menyesatkan dan membangkitkan emosi melalui judul yang sensasional banyak berseliweran di media sosial. Orang dengan tidak selektif membagikannya kepada temantemannya sehingga viral, sementara konten asli yang tidak mencolok tersembunyi di balik derasnya kebohongan. Kebohongan yang berulang-ulang disampaikan secara emosional itu akhirnya membangun keyakinan bahwa yang disampaikan itu adalah kebenaran. Inilah yang disebut fenomena pasca kebenaran (post-truth). Istilah yang pada 2016 dinobatkan sebagai "kata tahun ini" versi kamus Oxford itu dapat didefinisikan sebagai adjektiva yang "berhubungan atau menandakan keadaan saat fakta objektif menjadi kurang berpengaruh dalam membentuk opini publik dibandingkan daya tarik emosi dan keyakinan pribadi”. (McComiskey 2017, 5). Derasnya hoaks di era pasca kebenaran ini mempertajam polarisasi di masyarakat dan merusak relasi antar anggota keluarga dan antar sahabat, seperti terlihat jelas di Pemilihan Umum 2019. (Aminah dan Sari 2019).

Dalam dunia pendidikan, revolusi industri 4.0 turut serta mewarnai keberlangsungannya. Era revolusi industri 4.0 telah mengubah cara berpikir tentang pendidikan. Perubahan yang dibuat bukan hanya cara mengajar, tetapi jauh lebih penting adalah perubahan dalam perspektif konsep pendidikan itu 
sendiri. Mengembangkan soft skill dan transversal skill, serta keterampilan berguna dalam banyak situasi kerja seperti keterampilan interpersonal, hidup bersama, kemampuan menjadi warga negara yang berpikiran global, dan literasi media dan informasi. Pengembangan kurikulum pun harus mampu mengarahkan dan membentuk peserta didik yang siap menghadapi era revolusi industri dengan penekanan pada bidang Science, Technology, Engineering, dan Mathematics (STEM), serta berkarakter (Lase 2019). Pendidikan karakter itu sendiri tentunya tidak terlepas dari adanya praktek Pendidikan Agama Kristen (untuk selanjutnya ditulis PAK) yang berlandaskan kebenaran Alkitab.

Penggunaan gawai sebagai alat praktek PAK di era revolusi 4.0 tampak nyata terlihat di tengah kondisi pandemi COVID 19 yang berlangsung saat ini. Penyampaian Firman Tuhan dilakukan melalui siaran online karena dibatasinya pertemuan jemaat dalam jumlah yang besar; ibadah dilakukan dari rumah masingmasing. Media sosial sebagaimana Instagram, Facebook, Twitter pun menjadi sarana dalam penyampaian Firman Tuhan.

Kendati adanya penggunaan gawai dalam pemberitaan Firman Tuhan, Alkitab tetap harus menjadi teks terpenting, dan para pembicara atau penyampai Firman Tuhan juga harus menghayati apa yang disampaikannya kepada jemaat dalam seluruh segi kehidupannya. Seperti Budiono berkata, "Penyampai Firman Tuhan harus tetap menjaga kemurnian pemberitaannya namun tetap up to date, dengan semua sarana yang telah Tuhan sediakan di zaman ini, kepada masyarakat yang memiliki pengetahuan yang telah bertumbuh dalam perkembangan telekomunikasi yang pesat, perkembangan globalisasi dan keterbukaan terhadap 
berbagai informasi dan komunitas majemuk (pluralis) yang menjunjung tinggi kemanusiaan. Umat manusia harus dibawa kepada perjumpaan pribadi kepada Tuhan yang tidak berubah yang disampaikan dengan metode dan sarana yang senantiasa berubah". (Budiono 2018, 133).

Hal itulah yang menantang bagi orang Kristen untuk mampu menyikapi tantangan di era Revolusi Industri 4.0 dan pasca kebenaran sesuai dengan kehendak Tuhan. Karena itu gereja dan PAK di sekolah bertanggung jawab untuk menyampaikan kebenaran yang sejati dalam mendidik generasi muda Kristen yang tidak ketinggalan zaman dan mengikuti perkembangan teknologi, namun tetap mampu mempertahankan iman Kristen dan cara hidup yang semestinya dimiliki oleh orang Kristen.

Tulisan ini bertujuan untuk menjelaskan penggunaan gawai sebagai piranti teknologi, khususnya pada generasi muda, dan tantangannya di era Revolusi Industri 4.0 dan pasca kebenaran; bagaimana PAK pun dapat membantu untuk membimbing mereka menggunakan gawai secara cerdas dan sesuai kehendak Allah di era ini, khususnya dalam membangun relasi pribadi, keluarga, gereja dan masyarakat.

\section{METODE PENELITIAN}

Untuk mencapai tujuan penulisan tersebut, penulis menggunakan metode studi kepustakaan, kajian kualitatif deskriptif. Maksudnya, penulis akan menghimpun informasi yang relevan dengan Revolusi Industri 4.0, fenomena pasca kebenaran, serta membangun relasi secara Alkitabiah. 
Pertama, pencarian sumber-sumber yang dibutuhkan, baik berupa bukubuku, artikel-artikel pada jurnal, berita, serta sumber-sumber tertulis lainnya baik tercetak maupun yang dipublikasikan di internet.

Kedua, pengkajian dan pengumpulan bahan pustaka, yang memperhatikan terutama ide yang dibahas dan penjelasan pokok masalahnya. Bahan pustaka yang akan dihimpun sedapat mungkin yang belum terlalu lama ditulis, sehubungan dengan topik yang diangkat berhubungan dengan hal-hal mutakhir.

Ketiga, penyajian studi kepustakaan dalam pembahasan. Dengan studi kepustakaan, hubungan antara masalah, teori serta penelitian-penelitian yang relevan dengannya menjadi jelas, sehingga pembahasan lebih terfokus mengenai bagaimana PAK dapat berperan.

\section{HASIL PENELITIAN}

Setiap zaman memiliki momen perubahannya sendiri yang mendisrupsi kehidupan manusia. Istilah Revolusi Industri pertama kali digunakan untuk menyebut perubahan yang terjadi pada akhir abad ke-18 dan awal abad ke-19 dalam proses manufaktur akibat penemuan mesin uap yang dilanjutkan dengan pembangunan jalur kereta api. Mesin-mesin menggantikan cara produksi manual sehingga berdirilah pabrik-pabrik. Perubahan ini disebut sebagai revolusi, sebab memicu perubahan dalam bidang ekonomi, sosial dan budaya.

Karena teknologi berkembang terus, terjadilah Revolusi Industri kedua pada akhir abad ke-19 hingga awal abad ke-20 dengan pemanfaatan tenaga listrik dan jalur perakitan di pabrik-pabrik. Dalam kehidupan sehari-hari, masa ini juga 
memunculkan telepon, mobil dan pesawat terbang. Kemudian pada sekitar tahun 1960-an diawalilah Revolusi Industri ketiga sebagai akibat dari perkembangan komputer yang semakin kecil dan semakin tinggi kemampuannya, teknologi digital, hingga internet.

Mempertimbangkan apa yang telah terjadi dalam ketiga Revolusi Industri sebelumnya, maka Schwab berpendapat bahwa di awal abad ke-21 ini, dunia sedang berada di awal Revolusi Industri yang keempat. Ciri-cirinya adalah jaringan internet yang tersebar luas dan juga mobil, teknologi pengindraan yang berdaya dan murah, serta kecerdasan buatan (artificial intelligence) dan pemelajaran mesin (machine learning). (Schwab 2016).

Schwab juga menjabarkan teknologi-teknologi penggerak Revolusi Industri 4.0 yang dikelompokkannya menjadi tiga gugus: fisik, digital, dan biologis. Gugus fisik merupakan teknologi yang dapat dilihat dalam wujud nyata, meliputi kendaraan swakemudi, pencetakan tiga dimensi, robotika yang semakin canggih, hingga material baru seperti graphene. Gugus digital ditandai dengan Internet of Things (IoT) yang menghubungkan berbagai produk dan jasa yang bahkan terhubung dengan manusia menjadi hiper konektivitas, blockchain, serta ekonomi berbagi (sharing economy). Sementara gugus biologis mencakup biologi sintetis dengan pemrograman DNA, pengeditan gen, bioprinting atau produksi jaringan hidup, pemantauan kesehatan dengan teknologi, serta neuroteknologi. (Schwab 2016).

Tentu semua itu berdampak, baik di bidang ekonomi, bisnis, pemerintahan, sosial dan juga individual. Sehubungan dengan pembangunan relasi, dampaknya 
terhadap komunitas adalah tumbuhnya yang disebut masyarakat yang berpusat pada "aku" ("me-centered" society), yaitu pandangan bahwa komunitas itu dibangun dari proyek, nilai-nilai dan minat pribadi, tidak lagi berdasarkan ruang, pekerjaan dan keluarga. (Schwab 2016). Kemudian terhadap individu, Revolusi Industri 4.0 tentu berdampak pada bagaimana orang bertemu dengan orang lain dan membangun relasi, sebab teknologi membuat sentuhan antarmanusia berkurang.

Di era Revolusi Industri 4.0 ini, gawai sebagai piranti teknologi digunakan untuk berbagai hal, khususnya bagi generasi muda. Pertama, sebagai sarana untuk berkomunikasi dan berelasi. Sekarang orang lebih mudah berhubungan dengan orang lain di mana pun di dunia, sebab komunikasi instan melalui aplikasi pengirim pesan - WhatsApp, LINE, Telegram, WeChat, Facebook Messenger, dan sebagainya - serta media sosial-Facebook, Instagram, Twitter, dan sebagainya dapat melintasi batas geografis dan politis dunia. Tim Survei APJII (2019) menunjukkan bahwa pada 2018, alasan pertama pengguna Internet Indonesia menggunakan Internet adalah untuk berkomunikasi lewat pesan, sementara alasan kedua adalah media sosial.

Kedua, generasi muda menggunakan gawai untuk memperoleh informasi mengenai hal-hal yang mereka anggap penting atau menarik. Mereka dapat mencari informasi secara mandiri mengenai kerohanian, hiburan, hobi dan sebagainya, serta dapat pula menciptakan konten sendiri apabila mereka menginginkannya. Mereka dapat pula bertemu dengan orang-orang yang memiliki 
minat dan hobi yang sama sehingga membentuk komunitas daring secara efisien dalam skala besar.

Ketiga, generasi muda menggunakan gawai untuk bermain. Menurut laporan dari perusahaan survei Nielsen yang dikutip oleh Molla, 73\% orang Generasi Z di Amerika Serikat memiliki video game console. (Molla 2017). Di Indonesia memang tampaknya datanya tidak setinggi itu, tetapi jumlah pemain gim di kalangan generasi muda juga cukup banyak, sebab salah satu informasi yang dilaporkan oleh Tim Survei APJII (2019) adalah bahwa pada 2018, 17,1\% pengguna internet Indonesia menggunakan internet untuk bermain gim daring. Eugenio menjelaskan, gim daring memang memiliki banyak manfaat kognitif, seperti meningkatkan koordinasi, meningkatkan keterampilan memecahkan masalah, memperkuat ingatan, meningkatkan perhatian dan konsentrasi, menjadi media pembelajaran, meningkatkan kecepatan otak, memperkuat keterampilan multitugas, serta meningkatkan keterampilan social. (Eugenio 2017). Tetapi perlu diakui bahwa ada pula tantangan yang ditimbulkan.

Keempat, gawai menjadi piranti yang membantu generasi muda untuk belajar. Dengan gawai dan internet, pencarian informasi menjadi sangat mudah, sehingga belajar lebih diarahkan untuk mengelola, menata, menyusun, menafsirkan dan mengartikan informasi. Orang juga dapat dengan mudah berbagi pengetahuan dengan orang lain. Bagi anak-anak Indonesia, salah satu manfaat yang dapat dirasakan adalah meningkatnya kemampuan berbahasa Inggris, sebagai akibat banyaknya konten yang ditulis dalam bahasa Inggris. 
Namun di sisi lain, gawai sebagai piranti teknologi di Revolusi Industri 4.0 juga membangkitkan banyak tantangan. Pertama, menimbulkan kecanduan. Sebuah studi di Inggris melaporkan bahwa rata-rata orang Inggris mengecek ponsel mereka 221 kali dalam sehari-atau sekali setiap 4,3 menit. (Weisberg 2016). Ini tidak mengherankan, sebab gawai seperti ponsel pintar senantiasa berusaha merenggut perhatian pemiliknya dengan menayangkan notifikasi dari berbagai aplikasi. Elliot Berkman, profesor psikologi dari Universitas Oregon, mengatakan bahwa kecanduan gawai terjadi karena reward learning-perasaan positif yang diperoleh dari pengalaman serupa sebelumnya-dan dorongan sosial melalui takut dikatakan tidak update (Fear of Missing Out, FOMO). Kecanduan ini terjadi karena kebiasaan yang sulit dipatahkan akibat kesulitan bagi manusia untuk melawan fungsi otaknya sendiri. (Baral 2017).

Bagi generasi muda, terutama siswa sekolah dan mahasiswa, kecanduan gawai dapat menimbulkan kecemasan, depresi, tidak mau tidur di malam hari sehingga sulit berkonsentrasi di siang hari. Akibatnya prestasi akademis pun akan menurun. Perhatian mereka juga dapat teralih dari hal-hal yang seharusnya mereka perhatikan menjadi hal-hal yang kurang penting, seperti hiburan.

Kedua, orang menjadi merasa kesepian di tengah ramainya konten digital, sebab mereka tidak merasakan relasi di dunia nyata. Seperti kata Couric dalam sambutannya kepada para wisudawan Universitas Wisconsin-Madison:

Media sosial dapat menjadi sesuatu yang hebat: memberikan suara kepada yang tak bersuara, mempersatukan orang di seluruh dunia untuk maksud bersama. Tetapi hati-hati melangkah. Keterhubungan terus-menerus dapat membuat Anda merasa terisolasi dan terputus. Jangan tergoda oleh keintiman palsu dari media sosial. Penghiburan dan dukungan dapat 
ditemukan dalam komunitas daring, namun tidak dapat menggantikan kemanusiaan komunitas nyata. (Couric 2015).

Pengiriman pesan kepada orang lain melalui aplikasi pengirim pesan seperti WhatsApp atau Line serta media sosial seperti Facebook atau Twitter membuat orang menunggu, dan jika tanggapan atau komentar dari orang lain tidak kunjung tiba, membuat orang merasa seakan-akan tidak ada orang lain di sisi lain, dan mereka hanya berhadapan dengan layar yang mati. (Reinke 2017) mengemukakan hal ini sebagai dilema ayam dan telur: Apakah Facebook membuat kita kesepian, atau apakah Facebook menarik bagi kita yang memang sudah kesepian?

Gawai sebagai piranti teknologi juga membuat orang semakin terisolasi, sebab membuat orang dapat melakukan berbagai hal tanpa perlu bertemu dengan orang lain. Interaksi antarmanusia semakin tergantikan oleh interaksi antara manusia dengan mesin. Sebagai contoh transaksi di gerbang tol dilakukan dengan kartu uang elektronik, pembelian karcis kereta api dilakukan di mesin penjual otomatis, pengambilan uang dari tabungan bank dilakukan di mesin ATM, belanja dilakukan secara daring melalui situs perdagangan elektronik, pemesanan makanan dilakukan secara daring dengan aplikasi ojek daring, dan sebagainya. Teknologi memang selalu dirancang untuk memisahkan kita, dan isolasi kita itu memang diinginkan dan tercapai (Reinke 2017).

Rusaknya relasi akibat teknologi juga dapat berdampak pada keterampilan sosial dan kemampuan kita untuk berempati, mungkin karena orang sering tidak melihat lawan bicaranya secara langsung sehingga mudah tergoda untuk marah. Misalnya, Schwab mengutip studi dari tim Universitas Michigan pada 2010 yang menemukan anjloknya empati di antara mahasiswa sebanyak 40\% dibandingkan 
dengan mahasiswa 20 hingga 30 tahun yang lalu. Kebanyakan penurunan terjadi setelah tahun 2000. (Schwab 2016).

Ketiga, gawai membuat orang menjadi semakin narsistik. Reinke (2017) menjelaskan kecenderungan generasi muda yang berusaha sekuat tenaga untuk ingin diterima orang lain, dan karenanya berusaha untuk menonjol dan tampil berbeda. Mereka juga ingin menjadi seperti idolanya dan rela menghabiskan uang untuk hal-hal yang membuatnya tampil menonjol. Orang memang berjuang untuk diterima orang dengan cara yang menurutnya dipikirkan oleh orang lain tentangnya, seperti kata Charles Cooley, "I am not what I think I am, and I am not what you think I am. I am what I think you think I am." (Empath 2020). Dengan kata lain, gawai mendorong orang untuk menjadi serupa dengan dunia ini, bertentangan dengan Rm. 12:2.

Keempat, gawai membuat orang dapat terpapar konten negatif seperti pornografi, kekerasan, hoaks, serta ujaran kebencian. Tidak semua konten negatif ini mudah untuk di filter, sebab banyak pula yang berseliweran melalui komunikasi pribadi melalui aplikasi pengirim pesan dan media sosial. Tentu bagi generasi muda, hal ini dapat berdampak negatif sebab merusak karakter mereka. Pornografi memang masalah yang sudah menjalar. Reinke (2017) melakukan survei terhadap 8.000 orang Kristen dan menemukan bahwa hampir 50\% dari pria Kristen berusia 18 hingga 29 mengaku terus-menerus mengakses konten pornografi di internet.

Hoaks merupakan konten negatif yang menjadi masalah besar di era pasca kebenaran saat ini. Karena itulah, Paus Fransiskus dalam pesannya di Hari 
Komunikasi Dunia 2018 memilih tema "Berita Palsu dan Jurnalisme untuk Kedamaian.” (Francis 2018). Internet memang merupakan sarana yang mendorong kebohongan, sebab orang merasa tidak perlu jujur kepada orang lain yang tidak ditemuinya secara tatap muka. Riset yang dilakukan di Georgia Tech, MIT dan institusi lainnya menemukan bahwa di dunia daring, orang berbohong tentang segalanya, baik tentang jenis kelamin, pekerjaan, usia, serta tempat tinggal. (Keyes 2004). Tentu hoaks dan kebohongan berdampak negatif, seperti kecurigaan bahkan terhadap berita asli serta rusaknya hubungan antara sesama yang berpandangan berbeda, sebagai hasil dari polarisasi yang dibentuk dari kepercayaan terhadap kebohongan yang terus-menerus dialirkan terutama mengenai isu-isu Suku, Agama, Ras, dan Antar-golongan (SARA).

\section{PEMBAHASAN}

Dalam Amanat Agung-Nya, Tuhan Yesus mengatakan, "Dan ajarlah mereka melakukan segala sesuatu yang telah Kuperintahkan kepadamu.” (Mat. 28:20a). Rasul Paulus juga mengatakan bahwa Tuhan memberikan jabatan-jabatan, salah satunya pengajar, untuk memperlengkapi orang-orang kudus bagi pekerjaan pelayanan, bagi pembangunan tubuh Kristus (Ef. 4:11). Oleh karena itu PAK merupakan salah satu dari tugas-tugas gereja. Gereja tidak boleh memandang PAK sebagai suatu sambilan. PAK selayaknya terhisap dalam tugas gereja yang sah, sehingga harus dilaksanakan bersama oleh seluruh anggota jemaat. (Homrighausen dan Enklaar 2013). Sebab itu, gereja melalui PAK harus dapat membantu untuk mengasuh dan membimbing generasi muda Kristen dalam 
perspektif Kekristenan, sehingga mereka memiliki pedoman nilai-nilai Kristiani dalam penggunaan teknologi dan menghadapi tantangan-tantangannya.

Tentu langkah pertama yang harus diambil oleh PAK adalah tidak menolak teknologi, tetapi merangkulnya dan menggunakannya sebagai media pembelajaran. Revolusi Industri 4.0 membuka banyak peluang baru untuk meningkatkan dan memperkaya dunia pendidikan dengan teknologi, misalnya gamifikasi proses pembelajaran, multimedia canggih, hingga realitas tertambah (Augmented Reality, AR). Untuk itu para guru PAK tidak boleh gaptek dan harus mempelajari teknologi mutakhir yang relevan dengan proses pembelajaran yang dilakukannya serta memahami tantangan-tantangannya.

Teknologi dalam Revolusi Industri 4.0 juga mempermudah pendekatan heutagogi, yaitu pembelajaran yang bebas ditentukan sendiri oleh peserta didik. Heutagogi berpusat pada peserta didik alih-alih pendidik. Teknologi memberikan sumber belajar yang terbuka, edupunk, media sosial, massive open online courses (MOOC) dan digital badges, yang memungkinkan peserta didik lebih mampu mengendalikan apa yang dipelajarinya, bagaimana dan di mana mereka belajar. (Blaschke 2017). Untuk PAK di sekolah, heutagogi dapat digunakan untuk mendorong peserta didik giat mencari informasi terlebih dahulu di luar kelas secara mandiri, sehingga pertemuan tatap muka di dalam kelas dapat digunakan untuk lebih banyak mendiskusikan hal-hal yang menarik dari penggalian yang sudah dilakukan oleh peserta didik, memperdalam hal-hal yang penting, presentasi pribadi ataupun kelompok, serta gim pembelajaran seperti Kahoot!. 
Sebagai tugas yang membawa mandat untuk menghidupkan iman sehingga "berbuah dengan indahnya dalam hidup perseorangan, dalam persekutuan jemaat seanteronya dan juga dalam masyarakat umum" (Homrighausen dan Enklaar 2013, 25), PAK harus menekankan pentingnya membangun relasi dengan sesama. Joy berkata bahwa keselamatan sebetulnya adalah rencana besar untuk kembali kepada rencana penciptaan semula yaitu "agar manusia dapat hidup secara utuh dan intim dengan sesama dan dengan Allah.” (Joy 1996, 11).

Karena seluruh manusia diciptakan segambar dengan Allah (Kej. 1:27) maka sebagai salah satu materi pelajaran PAK harus diajarkan untuk memandang orang lain dengan kasih dan penghormatan tanpa membeda-bedakan latar belakang, keadaan fisik, pendidikan, jenis kelamin, suku, agama, ras, maupun status sosial ekonomi. Manusia harus saling mengasihi, karena Allah adalah kasih (Yoh. 13:34; 1Yoh. 4:7-8). Rasul Paulus juga mengajarkan agar orang Kristen mengasihi dengan tulus dan hidup harmonis dengan semua orang (Rm. 12:9-21). Ini diteladankan sendiri oleh sang Guru Agung, Tuhan Yesus sendiri yang menjalin relasi dengan siapa pun (Yoh. 4:1-45; Luk. 19:1-10; Mat. 8:5-13).

Tentu teknologi di era Revolusi Industri 4.0 dapat digunakan untuk membangun relasi, dan bahkan memungkinkan pembentukan komunitas maya sehingga koinonia dapat terjadi tanpa dibatasi oleh ruang dan waktu. Namun Ebersole dan Woods memperingatkan bahwa Injil mengharuskan sentuhan inkarnasional, dan persekutuan Kristen yang penuh dan otentik mengharuskan hubungan tatap muka. (Chechowich 2008). Firman Tuhan juga mengatakan bahwa kita harus bersekutu satu sama lain (1Yoh. 1:7), saling mendoakan (Yak. 
5:16), dan hidup harmonis dengan orang lain (Rm. 12:16). Karena itu pembangunan relasi tidak boleh dilakukan hanya melalui piranti teknologi. Di tengah perkembangan teknologi yang semakin maju ini, PAK harus mengajarkan pembangunan relasi dengan cara konvensional yaitu tatap muka. Media sosial dan aplikasi pengirim pesan harus diajarkan hanya sebagai pelengkap perjumpaan manusia secara nyata dan tatap muka. Dalam Alkitab, Yohanes mengatakan pertemuan secara langsung dengan jemaat lebih baik daripada surat tertulis, sebab menyempurnakan sukacita (2 Yoh. 12).

Di tengah pandemi COVID-19, sekolah-sekolah mengalihkan proses belajar-mengajar ke dunia online dengan menggunakan sistem manajemen kelas seperti Google Classroom, sementara pertemuan antara guru dan siswa dilakukan melalui konferensi video seperti Google Hangouts Meet atau Zoom. Namun konferensi video tetap tidak senyaman perjumpaan nyata. Banyak orang merasakan ketegangan dan ketidaknyamanan. Seperti dikatakan oleh DeggesWhite (2020), ketidaknyamanan ini terjadi karena komunikasi nonverbal yang seharusnya mengambil porsi $85 \%$ dari penyampaian pesan, tidak tersampaikan dengan sempurna. Orang jadi mengalami kesulitan dalam mengikuti percakapan dan tetap dalam jalur pembicaraan. Dalam hal ini PAK harus mengajarkan keunggulan pertemuan tatap muka yang menghasilkan sukacita alih-alih ketidaknyamanan, dalam kondisi normal di luar Pembatasan Sosial Berskala Besar (PSBB).

Untuk mengurangi kecanduan peserta didik atas gawainya, PAK dapat mengajarkan bahwa gangguan berupa keinginan daging, keinginan mata, 
keangkuhan hidup dapat membutakan mata orang tentang Tuhan dan bahkan dapat membinasakan (1Yoh. 2:16-17). Kalau peserta didik terus merasa nyaman dengan gangguan-gangguan sehingga tidak mengadakan waktu untuk duduk di kaki Tuhan dan tidak berjaga-jaga untuk menantikan kedatangan Tuhan, maka ketidaksiapan itu bagaikan hamba yang tidur dan tidak bertanggung jawab (Mrk. 13:33-37). Memang orang tidak dapat menghindarkan diri dari gangguan, tetapi gangguan yang disengaja perlu dikurangi, supaya orang Kristen dapat membangun relasi yang nyata dengan Allah dan sesama. Contohnya adalah melarang penggunaan gawai pribadi pada sebagian besar pelajaran di sekolah agar peserta didik dapat berfokus pada kegiatan belajar-mengajar, serta mengajarkan untuk meninggalkan gawai pada saat makan bersama keluarga. Untuk itu orang tua juga perlu ikut serta mendukung usaha ini, misalnya dengan mendampingi anak-anaknya saat menggunakan gawai serta tidak memberikan gawai pribadi kepada anak-anak yang masih terlalu kecil - misalnya yang masih duduk di bangku Sekolah Dasar.

Di tengah merosotnya empati di Revolusi Industri 4.0, PAK ternyata dapat memberikan pengertian kepada generasi muda Kristen bahwa bersengketa, bertengkar, saling menghakimi itu bertentangan dengan Firman Tuhan (Yak. 4:112). Generasi muda juga perlu diajar untuk tidak membanding-bandingkan dirinya dengan orang lain, tidak memaki, menghakimi, menyindir satu sama lain. Hanya Tuhan yang berhak membalas (Rm. 12:19), maka tanggung jawab kita hanyalah memberikan belas kasih kepada orang-orang yang memusuhi kita (Rm. 12:2021). 
Dalam menghadapi konten hoaks dan berita palsu, PAK mendukung upaya untuk membuat generasi muda Kristen lebih mampu membentengi diri dan mengenali hoaks. Caranya dengan meningkatkan literasi mereka melalui kebiasaan membaca dan menulis dengan tingkat pemahaman yang tinggi, serta mengajarkan kemampuan untuk memahami, menganalisis, menilai, serta menceritakan kembali suatu konten baik tertulis maupun multimedia. Sekolah dan gereja dapat pula melakukan pelatihan atau seminar mengenai hal ini.

PAK memberikan pemahaman bahwa hoaks dan berita palsu merupakan sesuatu yang tidak ditoleransi oleh Alkitab, sekalipun menjadi suatu tren di era pasca kebenaran seperti sekarang ini. Hoaks merupakan pekerjaan iblis, sebab iblis adalah bapa segala dusta (Yoh. 8:44). Sebaliknya Tuhan Yesus mengatakan diri-Nyalah sang kebenaran itu sendiri (Yoh. 14:6), dan kebenaran itu memerdekakan (Yoh. 8:32). Karena Tuhan Yesus mengajarkan untuk selalu berkata benar, bahkan sumpah pun tidak dibutuhkan lagi (Mat. 5:33-37). Kebohongan dan hoaks harus dihindari bukan hanya karena itu melanggar hukum, melainkan karena itu bertentangan dengan hati nurani.

Obat yang terampuh untuk mengatasi kepalsuan bukanlah strategi, melainkan manusianya. Karena itu PAK berperan dalam membentuk orang-orang Kristen yang sanggup menganalisis informasi dan mengekspresikan diri, terbuka untuk mendengarkan dan berdialog, menerima perbedaan, dan bertanggung jawab. Di sinilah relasi akhirnya terbangun sesuai dengan kebenaran Firman Tuhan.

PAK berperan penting untuk membuka mata generasi muda Kristen di era Revolusi Industri 4.0 dan Pasca-Kebenaran, bahwa Firman Tuhan yang tertulis 
dalam Alkitab masih sangat relevan untuk mengajar, menyatakan kesalahan, memperbaiki kelakukan, dan untuk mendidik orang dalam kebenaran (2Tim. 3:16). Dengan berpedoman pada Alkitab, PAK harus dapat menjawab tantangan untuk membangun relasi di tengah perkembangan teknologi yang sedikit banyak berpengaruh untuk melunturkan relasi nyata antarmanusia.

\section{KESIMPULAN}

Era Revolusi Industri 4.0 membawa banyak peluang positif untuk meningkatkan kehidupan manusia, dan karena itu orang Kristen pun harus menyambutnya dengan terbuka. Teknologi dapat menjadi sarana yang efektif dalam menyampaikan kebenaran Injil, karenanya harus dimanfaatkan dengan bijak, sebab setiap perkembangan dan inovasi teknologi baru juga menuntut tanggapan baru dari orang Kristen agar dapat menyikapinya secara Alkitabiah.

Sebagai salah satu tugas gereja yang penting, PAK harus mampu mengambil posisi sebagai pendidikan yang memiliki keunikan dibandingkan dengan pendidikan lainnya, yaitu tetap membimbing peserta didik dalam perspektif kekristenan dan memberikan pedoman pandangan dunia kekristenan dalam melihat, menilai, dan berinteraksi dengan dunia hari ini. Namun, untuk dapat tetap relevan dengan perkembangan zaman dan kebutuhan aktual, kemasan dan metode PAK harus disesuaikan sehingga mampu mendidik peserta didik untuk menjadi orang-orang Kristen yang unggul.

Dalam PAK, harus diajarkan cara membangun relasi yang Alkitabiah, yang tidak dibangun hanya dengan menggunakan teknologi dan piranti-piranti terkait seperti gawai, melakukan upaya untuk mengurangi kecanduan peserta didik atas 
gawainya, meningkatkan empati, serta menyampaikan kebenaran dan mengenali konten hoaks atau berita palsu.

Dengan beradaptasi terhadap perkembangan teknologi namun tetap pada posisi yang tidak serupa dengan dunia, maka PAK akan mampu membimbing peserta didiknya agar dapat menyadari bahwa sebagai manusia yang memiliki gambar Allah, mereka harus saling mengasihi sesama dan menjalin relasi yang harus dilakukan tidak hanya dengan teknologi, serta mengembangkan diri menjadi saksi-saksi Kristus yang tetap memegang teguh kebenaran-Nya di tengah derasnya kebohongan dan kepalsuan.

Untuk mendapatkan informasi yang lebih detil berkenaan dengan fakta yang terjadi di lapangan, maka peneliti menyarankan agar penelitian selanjutnya dapat dilakukan dengan menggunakan metode kuantitatif yang menyertai wawancara kepada nara sumber di mana secara spesifik subyek penelitiannya adalah SD, SMP, maupun SMA yang mendapat pelajaran PAK di era Revolusi Industri 4.0 ini.

\section{DAFTAR PUSTAKA}

Aminah, Aminah, dan Novita Sari. 2019. "Dampak Hoax di Media Sosial Facebook Terhadap Pemilih Pemula.” Jurnal Komunikasi Global 8 (1): 5161. https://doi.org/10.24815/jkg.v8i1.13565.

APJII. 2019. “Buletin APJII Edisi 40 - Mei 2019,” 2019.

Baral, Susmita. 2017. "How to break the habit of checking your phone all the time." 2017. https://www.mic.com/articles/164230/how-to-break-the-habitof-checking-your-phone-all-the-time.

Blaschke, Lisa Marie. 2017. "Self-determined learning (Heutagogy) and digital media creating integrated educational environments for developing lifelong learning skills." In The Digital Turn in Higher Education: International 
Perspectives on Learning and Teaching in a Changing World, 130-40. Springer Fachmedien Wiesbaden. https://doi.org/10.1007/978-3-658-199258_10.

Budiono, Aryanto. 2018. "Inovasi Pengajaran Firman di Era Revolusi Industri 4.0.” PRUDENTIA: Jurnal Teologi dan Pendidikan Kristiani 1 (2): 124-34.

Chechowich, F. E. 2008. "Our Global Task of Fellowship-Community: Life in the Body of Christ." In Introduction to Christian Education and Formation: A Lifelong Plan for Christ-Centered Restoration, diedit oleh R. T. Habermas, 191-95. Zondervan.

Couric, Katie. 2015. "Katie Couric to Grads: Get Yourself Noticed | TIME." 2015. https://time.com/collection-post/3882654/katie-couric-graduationspeech-2015/.

Degges-White, Suzanne. 2020. "Dealing With Zoom Anxiety | Psychology Today." Psychology Today. 2020. https://www.psychologytoday.com/ us/blog/lifetime-connections/202004/dealing-zoom-anxiety.

Empath, Socio. 2020. "Charles Cooley: I Am What I Think You Think I Am." SmartCasualSG. 2020. http://www.smartcasualsg.com/charles-cooleysociology-quotes/.

Eugenio, Sheila. 2017. "8 Cognitive Benefits of Playing Video Games for Kids." 2017. https://www.engadget.com/2017-02-09-8-cognitive-benefits-ofplaying-video-games-for-kids.html.

Francis. 2018. "MESSAGE OF HIS HOLINESS POPE FRANCIS FOR WORLD COMMUNICATIONS DAY." 2018. http://www.vatican.va/content/ francesco/en/messages/communications/documents/papa-francesco_ 20180124_messaggio-comunicazioni-sociali.html.

Homrighausen, E.G., dan I.H. Enklaar. 2013. Pendidikan Agama Kristen. Jakarta: BPK Gunung Mulia.

Joy, Donald M. (Donald Marvin). 1996. Bonding : relationships in the image of God. 2nd ed. Nappanee Ind.: Evangel Pub. House.

Keyes, Ralph. 2004. The post-truth era: dishonesty and deception in contemporary life. 1st ed. New York: St. Martin's Press.

Lase, Delipiter. 2019. "Pendidikan di Era Revolusi Industri 4.0." SUNDERMANN: Jurnal Ilmiah Teologi, Pendidikan, Sains, Humaniora dan Kebudayaan 1 (1): 28-43. https://doi.org/10.36588/sundermann.v1i1.18.

McComiskey, Bruce. 2017. Post-Truth Rhetoric and Composition. Post-Truth 
Rhetoric and Composition. Logan: Utah State University Press. https://doi.org/10.2307/j.ctt1w76tbg.

Molla, Rani. 2017. "Millennials have a Netflix account. Gen Z is playing video games." https://www.vox.com/. 2017. https://www.vox.com/2017/ 7/17/15961370/millennials-netflix-account-gen-z-video-games-mobilephone-nielsen.

Reinke, T. 2017. "12 Ways Your Phone Is Changing You [ePub Version]." crossway.org. 2017. www.crossway.org.

Schwab, Klaus. 2016. The Fourth Industrial Revolution. Geneva: World Economic Forum.

Weisberg, Jacob. 2016. "We Are Hopelessly Hooked | by Jacob Weisberg | The New York Review of Books." 2016. https://www.nybooks.com/ articles/2016/02/25/we-are-hopelessly-hooked/. 